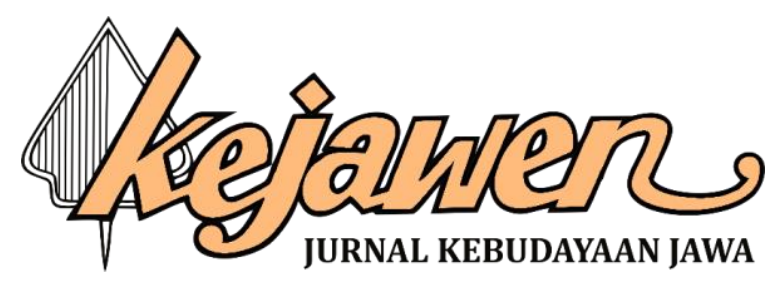

\title{
RELEVANSI TOKOH KUMBAKARNA DALAM SERAT RAMAWIJAYA SEBAGAI REFLEKSI SEMANGAT PATRIOSTISME PEMUDA INDONESIA
}

\author{
Dinda Ayu Hernawati, Respati Retno Utami \\ Universitas Negeri Surabaya \\ dinda.18026@mhs.unesa.ac.id, respatiutami@unesa.ac.id
}

\begin{abstract}
Abstrak
Sering kita ketahui bahwa beberapa tahun terakhir pemuda Indonesia sedang mengalami banyak masalah utamanya dalam hal semangat bela negara. Salah satu sikap yang semestinya dimiliki dalam hal bela negara tentunya adalah patriotisme. Pembahasan sikap patriotisme ini nantinya akan direlevansikan dengan watak tokoh kumbakarna dalam Serat Ramawijaya yang bertujuan menjadi refleksi pada semangat patriotisme pemuda di Indonesia. Ada beberapa metode dan model analisis data yang pas digunakan pada penelitian ini yaitu observasi, angket, dan wawancara. Sedangkan penggunaan analisis data dengan kualitatif deskriptif dan studi pustaka. Hal utama yang menjadi bagian dari kajian ini adalah teori strukturalisme genetik yang cocok untuk meneliti keterkaitan antara patriotisme dengan sifat atau watak tokoh Kumbakarna dan kenyataan yang terjadi di masyarakat. Dari hasil pembahasan tersebut diperoleh bagaimana sikap yang seharusnya dilakukan oleh seorang pemuda di Indonesia ini mengenai Patriotisme melalui refleksi dari tokoh Kumbakarna yang ada dalam Serat Ramawijaya. Sehingga dapat ditarik kesimpulan bahwa patriotisme tidak dilandasi atas kepentingan pribadi melainkan menjaga dan merawat sikap tersebut dengan memulainya dari kesungguhan hati nurani.
\end{abstract}

Kata kunci: Ramawijaya, Kumbakarna, patriotisme, strukturalisme

\section{KUMBAKARNA FIGURE RELEVANCE IN SERAT RAMAWIJAYA AS A REFLECTION OF THE SPIRIT OF INDONESIAN YOUTH PATRIOTISM}

\begin{abstract}
We often know that the last few years, Indonesian youth are experiencing many problems, especially in terms of the spirit of defending the country. One of the attitudes that should be had in terms of defending the country is of course patriotism. The discussion of this patriotism attitude will later be relevant to the character of the kumbakarna character in Serat Ramawijaya which aims to be a reflection on the spirit of youth patriotism in Indonesia. There are several methods and models of data analysis that are suitable for use in this study, namely observation, questionnaires, and interviews. While the use of data analysis with descriptive qualitative and literature study. The main thing that is part of this study is the theory of genetic structuralism which is suitable for examining the relationship between patriotism and the character of Kumbakarna figures and the reality that occurs in society. From the results of the discussion, it was obtained how the attitude should be taken by a young man in Indonesia regarding patriotism through the reflection of the Kumbakarna figure in Serat Ramawijaya. So it can be concluded that patriotism is not based on personal interests but rather maintains and cares for this attitude by starting from a serious conscience.
\end{abstract}

Keywords: Ramawijaya, Kumbakana, patriotisme, structuralism 


\section{PENDAHULUAN}

Sikap patriotisme akhir-akhir ini menjadi perhatian yang perlu ditekankan. Apalagi ditambah dengan kemajuan zaman dan pengaruh budaya dari negara lain yang semakin nyata pada negara Indonesia. Mulai dari sikap, kepribadian, bahkan sampai dengan semangat bela negara. Seakan-akan pemuda Indonesia menjadi kehilangan rasa cinta pada negara dan tanah airnya sendiri. Selain itu, jika tidak dilandasi dengan semangat patriotisme yang kuat akan menimbulkan degradai moral pada warga negara Indonesia khusunya kalangan pemuda. Hal ini dikarenakan pemuda memiliki tanggungjawab yang besar atas majunya dalam segi apapun, terutama dalam berkarya dan menjaga keutuhan negara. Maka dari itu sangat dibutuhkan generasi penerus memiliki sikap yang mengedepankan semangat juang. Sesuai dengan pendapat ahli yaitu Putri,dkk (2015:3) yang menyebutkan bahwa sikap patriotisme ini adalah bagian dari sikap perwujudan cinta terhadap tanah air dan lebih mementingkan kepentingan bangsa diatas kepentingan pribadi. Patriotisme juga menjadi bagian jiwa yang membara dari semangat cinta tanah air yang dilengkapi dengan eksistensi nasionalisme (Bakry, 2010:144). Penelitian ini akan menghubungkan antara semangat patriotisme pemuda Indonesia dengan watak tokoh Kumbakarna dalam Serat Ramawijaya. Alasan memilih watak tokoh Kumbakarna dalam penelitian ini dikarenakan Kumbakarna dikenal sebagai ksatria gagah perkasa yang setia meskipun dia adalah raksasa yang menyeramkan.

Penelitian mengenai Serat Ramawijaya sebelumnya sudah pernah dilakukan oleh Tio Cahya Sadewa mahasiswa Universitas Gadjah Mada Prodi Satra Jawa yang adengan judul Rubrikasi dalam Naskah Serat Rama (PB 1.243/L291) Koleksi Perpustaakn Museum Sonobudoyo Yogyakarta. Kemudian diteliti juga dalam sebuah tesis dengan judul Repertoire dalam Serat Rama: Suntingan Teks, Terjemahan, dan Analisis Repson Estetik Wolfgang Iser oleh Mardhayu Wulan Sari pada tahun 2015 program S2 Ilmu Sastra. Selain itu juga diteliti oleh Marsono dari Fakultas Ilmu Budaya UGM mengenai Amanat Kepemimpinan Ideal Asthabrata dalam Serat Rama Yasadipura (Analisis Intertekstual).

Umumnya pada penelitian yang sudah dibahas ini hanya mengedepankan satu variabel saja. Misalnya ada penelitian serupa yang hanya membahas tentang ilmu kepemimpinan, budi pekerti, ataupun nilai moral. Bisa dibilang dalam penelitian yang pernah dilakukan hanya satu variabel saja. Sedangkan pada penelitian ini membahas semangat patriotisme yang ada pada salah satu tokoh dan mengaitkannya dengan semangat juang yang ada pada pemuda Indonesia saat ini. Teori yang digunakan dalam penelitian ini adalah teori strukturalisme Genetik dari Lucien Goldman yang merupakan seorang filsuf dan sosiolog Rumania-Perancis. Teori tersebut dikemukakan dalam bukunya yang berjudul "The Hidden God: A study of Tragic Vision in the Penses of Pascal and the Tragedies of Racine" dalam bahasa Perancis terbit pertama kali tahun 1956. Teori ini merupakan teori yang memadukan antara struktur teks, konteks sosial, dan juga pandangan pengarang (Yasa, 2012:28). Dengan begitu karya sastra jika diteliti dengan teori strukturalisme genetik ini akan mengukur tanggapan manusia mengenai sebuah kekuatan sosial utamanya adalah bagaimana sifat, karakter pada tokoh yang akan diteliti. Teori yang menjadi teori dasar pada penelitian ini tentunya adalah teori filologi . Hal ini dikarenakan sudah semestinya jika suatu penelitian pada naskah kuna sangat dibutuhkan teori mengenai naskah kuna agar bisa membahas lebih dalam pada penelitiannya. Menurut Bambang Purnomo (2013:1) menyebutkan bahawa teori filologi ini adalah sebuat ilmu yang berhubungan dengan naskah lama. Sehingga di dalamnya tentu berkaitan dengan teks dan naskah serta sistematika dan metodik berupaya untuk membahas teks-teks lama yang tersimpan di dalam naskah. Sehingga dengan begitu dikatakan unik dan nantinya diharapkan menjadi salah satu motivasi untuk pemuda Indonesia agar meneladani watak tokoh yang ada. Berdasarkan uraian pendahuluan latar belakang di atas, penulis merumuskan dua permasalahan yakni sebagai berikut: (1)Bagaimanakah deskripsi tokoh Kumbakarna dalam Serat Ramawijaya?; ( 2) Bagaimana relevansi tokoh Kumbakarna dalam Serat Ramawijaya sebagai refleksi semagat patriotisme pemuda Indonesia?; Dari rumusan masalah 
tersebut kita dapat mengetahui (1) deskripsi mengenai tokoh Kumbakarna dalam Serat Ramawijaya (2) mengetahui relevansi tokoh Kumbakarna dalam Serat Ramawijaya sebagai refleksi semangat patriotisme pemuda Indonesia.

\section{METODE}

Untuk menggali betapa pentingnya semangat patriotisme yang ada pada tokoh Kumbakarna pada Serat Ramawijaya ini ada beberapa yang harus diperhatikan yakni penggunaan metode, analisis data dari data utama dan juga teori pada sebuah penelitian. Penelitian pada kali ini terdiri atas metode pengumpulan data dan metode analisis data. Beberapa metode pengumpulan data yang digunakan adalah sebagai berikut: (1) metode observasi: metode observasi adalah sebuah metode yang dilakukan dengan suatu pengamatan secara langsung. Melalui metode observasi dianggap sebagai metode yang pas untuk mendapatkan data yang lengkap. SusanStainback (1988) menyatakan bahwa "in participant observation, the researcher observes what people do, listen to what the say, abd participates in their activities". Dalam observasi, peneliti mengamati apa yang dikerjakan orang, mendengarkan apa yang mereka ucapkan, dan berpartisipasi dalam aktivitas mereka. (2) Metode wawancara: metode yang kedua pada penelitian ini adalah penggunaan metode wawancara. Menurut Esterberg dalam Sugiyono (2015:72) menjelaskan bahwa metode wawancara merupakan sebuah metode yang melibatkan dua oang dengan tujuan bertukar informasi dan bertanya jawab. (3) Metode angket: metode angket ini adalah metode yang terakhir untuk penelitian pada tokoh kumbakarna ini. Tujuan utama disertakan metode angkat ini adalah teknik pengumpulan data dengan cara mengirimkan suatu daftar pertanyaan kepada responden untuk diisi. Pada penelitian kali ini menggunakan beberapa metode analisis data diantaranya adalah sebagai berikut: (1) analisis kualitatif naratif: Analisis data kualitatif ini menekankan pada bagian kritik ini merupakan bagian dari kritik yang dilakukan melalui pendekatan terhadap teks dengan menggunakan kategori-kategori penyusun suatu kisah, sepertiplot,tokoh, dan sudut pandang. (2) analisis kualitatif wacana: Analisis data kualitatif ini meneliti atau menganalisis suatu unsur kebahasaan yang digunakan secara alamiah, baik dalam bentuk tulis maupun lisan terhadap para pengguna sebagai suatu elemen masyarakat. Sedangkan penggunaan studi pustaka yakni langkah yang dilakukan setelah peneliti menetapkan topik kemudian melakukak kajian teoritis dengan mencari referensi relevan (Sugiyono, 2017:291).

\section{HASIL DAN PEMBAHASAN}

Perlu diketahui bahwa Serat Ramawijaya ini didapatkan di Museum Kambang Putih Tuban dengan nomer inventaris MKP-S3. Bahan sampulnya terbuat dari yang tidak menggnakan garis, warna tintanya adalah hitam. Sedangkan mengenai tata cara penulisannya adalah menggunakan recto verso, dengan ukuran tulisannya adalah besar dan agak ke kanan. Pada pembahasan ini akan ditekankan pada tokoh Kumbakarna yang akan dikaitkan dengan Patriotisme sebagai refleksi pemuda Indonesia. Patriotisme berasal dari bahasa Inggris yaitu dari kata "patriotism" yang mempunyai makna dan juga arti adanya jiwa yang muncul terhadap kepahlawanan. Patriotisme juga berasal dari bahasa Greek yakni "patriots" yang berarti rekan senegara dan patrice yang bermakna fatherland atau country, yaitu tanah air atau negara. Menurut Syahri, dkk (2013:38) menyebutkan bahwa patriotisme adalah sebuah semangat yang dipersembahkan kepada tanah air dan rela berkorban atas kemakmuran tanah airnya tersebut. Sesuai dengan pendapat kedua ahli tersebut bahwa patriotisme adalah segala usaha yang harus dilandasi atas cinta yang besar terhadap nusa dan bangsa. Suatu hal yang berkaitan dengan patriotisme pasti dilandasi atas kegigihan dan kerja keras. Berikut adalah enam indikator dari patriotisme menurut Iskandar dalam Nugraha (2014:2): 1) Rasa Bangga terhadap Tanah Air; 2) Rasa ke-Bhineka Tunggal Ika; 3) Rasa Semangat Perjuangan; 4) Rasa Semangar Persatuan; 5) Diplomasi; dan 6) Rasa Cinta Tanah Air. Untuk lebih jelasnya berikut ini adalah deskripsi tokoh Kumbakarna secara terperinci: 


\section{Deskripsi Tokoh Kumbakarna dalam Serat Ramawijaya}

Kumbakarna adalah salah satu tokoh wayang yang berasal dari kehidupan Angkara murka. Terlahir dari raja bernama Resi Wisrawa, dengan ketiga saudara-saudaranya yaitu Rahwana, Sarpakenaka, dan Gunawan Wibisana. Meskipun keempat bersaudara tersebut sama-sama raksasa, tetapi secara watak dan kepribadian memiliki perbedaan yang sangat memonjol. Hal ini dikarenakan Rahwana dan Sarpakaneka memiliki watak yang kurang baik sedangkan Kumbakarna dan Gunawan Wibisana memiliki watak dan kepribadian yang jujur dan baik. Kumbakarna ini juga sering kali disebut dengan Arya Kumbakarna. Semangat patriotisme bela negara pada tokoh kumbakarna ini dapat dilihat pada kekukuhannya saat ia membela Rahwana kakaknya yang dianggap jahat itu ketika sedang berperang dengan Ramawijaya. Akan tetapi karena Kumbakarna ini tidak mau negaranya menjadi terpecah belah.Pasukan Rama menyerang negara Ngalengka dengan pasukan kera dan masih banyak hewan-hewan pendukung lainnya seperti Badak, Kutu, Anjing, dan hewan-hewan lainnya. Kumbakarna dihantam oleh pasukan kera pada saat perang tersebut. Bahkan satu persatu dari pasukan kera berhasil ditaklukan oleh Kumbakarna. Akan tetapi ada suatu hal tragedi yang menyedihkan pada saat itu, mau tidak mau takdir Kumbakarna gugur dalam melawan Ramawijaya. Untuk lebih jelasnya berikut ini adalah beberapa petikan pada Serat Ramawijaya:

\section{Kumbakarna sosok pemberani}

Kumbakarana dalam Serat Ramawijaya ini diceritakan sebagai sosok yang pemberani dan tidak takut dengan apapun yang terjadi. Indikator keberanian adalah sebuah tindakan yang menunjukkan suebuah perjuangan dimana perjuangan tersebut sangatlah penting. Menurut Aristoteles keberanian adalah "The Conquering of fear is the beginning of wisdom",yang berate bawha didalam keberanian harus ada penaklukan rasa takut dan awal sebuah sikap bijak dalam diri seseorang. Dia tangguh dan pantang menyerah dengan keadaan yang ada. Petikan berikut menunjukkan adanya bukti dari keberaniannya :

\section{//Dasamuka Sri Prabupati/ Kurdakané Mahéndra éndal Ki prastha mugên ngarsané/Ajajar Ki Kumbakarna /Dêrajit lan Bibisana/Ajajar gêni langguh/Kadya wukir jêjagongan// (Pupuh Asmarandhana-Gatra kaping 100) \\ Terjemahan: \\ //Dasamuka Sri Prabupati/ Mahendra memperlihatkan nafsunya/ punggungnya yang ada di depan/ Bersanding dengan Ki Kumbakarna / Derajit dan Bibisana/Bersandingan dengan sebuah api/ Seperti halnya gunung yang bercengkrama// (Tembang Asmarandha baris ke 100)}

Petikan naskah diatas menunjukkan bahwa Kumbakarna adalah sosok yang pemberani terhadap apapun yang dianggapnya benar. Ia tidak peduli apapun yang terjadi ketika peperangan akan datang. Bahkan meskipun berhadapan dengan Dasamuka seorang bupati di kerajaan besar negara Ngalengka, Kumbakarna tetap berpegang teguh atas sikap dan keberaniannya. Dalam petikan tersebut juga dijelaskan bahwa Kumbakarna mampu membela kebenaran yang dilatarbelakangi dengan kekisruhan pendapat antara dia dan juga saudaranya yakni Bibisana atau Wibisana. "Wibisana itu memang menjadi musuhnya. Padahal Wibisana ini merupakan adik aslinya Kumbakarna. Tetapi Wibisana itu mengerti kalau kakanya Rahwana kan melakukan kesalahan, makanya dia beralih dan membela Sri Rama atau Prabu Rama.

Menurut pengetahuan saya seperti itu, kan sudah jelas juga kalau Kumbakarna ini memiliki saudara kandung yaitu Rahwana, Kumbakarna, Sarpakenaka, dan Wibisana (Wawancara dengan Mohammad Saifuddin Zuhri, 24 Tahun). Kita ketahui, bahwa tidak mudah melakukan dan menjadi sosok yang pemberani untuk mengambil suatu risiko jika itu berhubungan dengan saudara kandung sendiri. Tapi, karena keteguhan yang ada yakni Kumbarna tidak ingin terjadi peperangan 
dan tetap membela Rahwana atas dasar kecintaannya terhadap negeri Ngalengka, jadilah keberanian yang didasari atas cinta negar tersebut. Terdapat sesuatu yang paling unik dari kilas balik pembelaan Wibisana terhadap Rama yakni ketika Kumbakarna memiliki keinginan yang baik untuk mengobati rasa rindunya dengan sang adik yaitu Wibisana meskipun dalam keadaan darurat. Berikut beberapa kutipannya:

\begin{abstract}
//Dumeh kakang yen prawira/Ateguh luput ngemasi/Ngandelaken polesan/Meksih setya pramesthi/ Sumangga teluk nuli/ Dasamuka kurda muwus/ Kumbakarna wo keparat/ Anggung gawe mamrih / Lir si kakang lumaku dipunturutal/ (Pupuh Sinom-Gatra kaping 109)

Terjemahan:

//Karena jika kakak berani/Tidak akan gugur/ Memberanikan akan sebuah perubahan/ Masih setia sang Dewa/ Silakan bergegas untuk mengalahkannya/ Dasamuka berbicara dengan penuh nafsu amarah/ Kumbakarna orang keparat/ Selalu membuatku berbuat pamrih (selalu mengedepankan amarah)/ Seperti meniru jalan kakaknya. (Tembang Sinom-Baris ke 109)
\end{abstract}

Saat itu memang dalam keadaan yang sangat gaduh terjadi di negara Ngalengka. Bahkan Dsamuka juga sempat menjuluki Kumbakarna orang yang keparat. Tidak mau dan tidak berani melawan Prabu Rama. Dasamuka juga mengatakan bahwa Kumbakarna merupakan sosok yang tidak ada bedanya dengan Rahwana kakanya. Dasamuka sangat marah dengan sikap Kumbakarna saat itu. Tetapi Kumbakarna merupakan sosok yang pemberani, meskipun diejek sedemikiran rupa tetap Kumbakarna berani maju ke medan perang.

\title{
Kumbakarna sosok penuh keyakinan dan strategi
}

Selain sosok pemberani, Kumbakarna adalah sosok yang dipenuhi dengan sosok pejuang yang mengerti stretegi lawan. Perjuangan dalam kerendahan hatinya memperdalam dirinya mengetahui sosok strategi lawan perangnya. Berikut ini adalah kutipan Serat Ramawijaya mengenai sosok Kumbakarna yang paham tentang strategi perang lawan.

\section{//Aku mandraguna sêkti/ aku bisa nata jagat/ kumbakarna matur alon/ sampun Bêthara Rama/ tan samar kawula dulu/ sawungé ing Suralayall (Pupuh Asmarandhana-Gatra kaping 103) \\ Terjemahan : \\ //Aku orang yang sakti mandraguna/Aku bisa menata dunia/Kumbakarna berkata dengan pelan/Sudahlah Bethara Rama/ Pandangan saya tidak samar/ Jagonya di khayangan// (Tembang Asmarandhana- Baris ke 103)}

Petikan data pada Serat Ramawijaya diatas menunjukkan bahwa Kumbakarna merupakan sosok yang penuh dengan strategi lawan bicaranya. Dia memilih berkata dengan kerendahan hatinya atau biasa dibilang bagi masyarakat Jawa adalah "Ora neka-neka". Hal tersebut memperkuat tokoh Kumbakarna untuk tetap optimis dan penuh dengan strategi. Kumbakarna biasanya juga dijuluki dengan sebutan sebagai Arya kumbakarna. Bahkan karena kesabaran dan kesetiaannya pada pertapaan menjadikan ia berhasil dan bisa memperoleh sebuah ilmu kesaktiannya yaitu ilmu Pethakgelapsakti, Gedhongmega, dan Cikralasuta. Segala kemurnian dan kesabarannya itu menjadikan ia memperoleh apa yang ia butuhkan pada negera Alengka. Dapat dikatakan bahwa Kumbakarna adalah sosok yang tetap rendah hati. Meskipun Kumbakarna ini dikatakan sebagai raksaasa yang besar dan tingginya diatas rata-rata, Kumbakarna sangatlah berbeda dari saudara-saudaranya (Suhardi, 2013:87). Memang terkesan mengerikan, tapi Kumbakarna adalah simbol keprawiraaan baktinya kepada negara Ngalengka. Sosok Kumbakarna 
tidak pernah menghakimi, dia mengingatkan kepada kakaknya Rahwana untuk tidak berbuat sedemikian yang dibilang tidak terpuji. Bahkan karena sifat pejuangnya juga, Kumbakarna memiliki sebutan sebagai panglima perang yang handal.

\title{
Kumbakarna memiliki cinta yang besar terhadap negara Ngalengka
}

Selain dianggap sebagai panglima perang yang handal, Kumbakarna juga tidak segansegan mengucapkan apa yang terjadi secara nyata. Maksud mengucapkan yang terjadi secara nyata adalah Kumbakarna tidak segan-segan untuk cekatan dalam berbagi ilmu kepada orang sekitar. Misalnya seperti apa yang sudah ia katakana kepada adiknya sendiri yaitu Bibisana atau Wibisana. Beikut petkan datanya dalam naskah Serat Ramawijaya:

\begin{abstract}
//Bibisana matur aris/inggih kakang Kumbakarnal Lêrês kakang aturél inggih kakang Kumbakarnal Yêktiné Bêthara Ramal Prajurité Sang Hyang Guru/ Sawungé ing ngarsa padall (Pupuh Asmarandhana-Gatra kaping 106)

Terjemahan :

//Bibisana berkaya pelan/ Iya Kakak Kumbakarna/ Benar apa yang kakak katakana/ Iya Kakak Kumbakarna/Kenyataannya adalah Bethara Rama/ Prajuritnya Sang Hyang Guru/ Jagonya yang berada di depan// (Tembang Asmarandhana-Baris ke 106)
\end{abstract}

Petikan Serat Ramawijaya diatas menunjukkan bahwa Kumbakarna tidak segan-segan mengingatkan sesamanya. Meskipun saat itu bisa dikatakan bahwa Wibisana dianggap sebagai musuhnya sendiri. Memang ada beberapa versi yang menjelaskan bahwa sebenarnya mereka berdua tidak bertengkar, tapi Wibisana juga tidak salah. Pandangan Wibisana mengenai kakaknya ini sangatlah luas, dianggapnya Rahwana ini memang sangat keluar dari norma negara ngalengka kala itu. Rahwana telah menculik Dewi Sita sampai-sampai kabar ini menjadi perbincangan yang tak mengenakkan dari saudara-saudara Wibisana termasuk juga Kumbakarna. Sampai akhirnya terjadi peperanganpun Wibisana tetap berpihak kepada Rama. Berbeda dengan Kumbakarna yang tetap bersikeras untuk menyelamatkan negara Ngalengka. Kumbakarna tidak mau negaranya terpecah belah hanya karena perilaku dan tingkah yang dilakukan oleh Rahwana kakak pertamanya itu. Kumbakarna bahkan dikatakan sebagai sosok yang membela kepicikan Rahwana tersebut karena telah berjuang melawan Rama. Namun Kumbakarna tetap tidak peduli. Tujuan utama dalam menyelamatkan negara Ngalengka adalah hal yang lebih utama dari pada tujuan tak penting alinnya. Kumbakarna bersikeras untuk tetap melawan sang Rama dengan segala kekuatan yang ada itu. Suatu ketika Kumbakarna sedang ingin maju di medan perang.(Ariani, 2013:78). Akan tetapi ada suatu hal yang menjadikan bahwa dia memang benar-benar tulus dalam menjaga negara Ngalengka. Dia bahkan tetap menanyakan bagaimana nanti jika kakanya Rahwana terjadi apa-apa. Sat itu juga Riwonda datang dan menggembor-gemborkan untuk menghancurkan Keraton Ngalengka. Berikut ini adalah cuplikannya secara langsung:

//Riwonda wus ngêpung pura/ Sintên ingkang maju jurit/ Kumbakarna angandika/ Mêngko kakang ana endi/ Gugua atur mami/ Tur masa kasiyat gêmpur/ Iya nêgara ngalengka/ Mêngko kakang ana ngêndi/ Sigra seba ki arya kumbakarnal/ (Pupuh Sinom-Gatra kaping 107)

Terjemahan:

//Riwonda sudah mengepung pura/ Siapa yang akan maju untuk berperang/ Kumbakarna berkata/ Nanti kakak ada dimana/ Percayalah apa yang aku katakana/ Dan juga lamanya daya tahan akan runtuhnya/ Iya negara ngalengka/ Nanti kakak ada dimana/ Lalu menghadaplah ki arya kumbakarna// (Tembang Sinom- Baris ke 107) 
Cuplikan data di atas menunjukkan tentang kekhawatiran yang menyelimuti negara Ngalengka. Apalagi dikatakab bahwa pasukan kera (Riwonda) sebagai utusanb Prabu Rama kala itu sudah mengepung negara Ngalengka agar bisa druntuhkan. Tak lama kemudian Kumbakarna tetap berfikir, dia mencari keberadaan Rahwana kala itu. Karena hal utama atau masalah uta yang menjadikan negara Ngalengka terpecah belah adalah tingkah Rahwana yang berusaha mengambil cintanya Sita kepada Rama. Karena atas dasar cinta itu tadi akhirnya Kumbakarna bergegas melakukan apapun yang ia anggap bisa menyelamatkan negaranya itu.

\section{Kumbakarna berkepribadian kuat dan tidak mau dianggap lemah oleh lawan}

Selain karena rasa cinta dan nasonalisme yang menyala dalam diri Kumbakarna,sebuah kegigihan tetap tertuang dalam pribadi Kumbarna meski dalam serangan lawan. Hal ini sesuai dengan petikan dalam Serat Ramawijaya dibawah ini:

\section{I/Tuhu mêsti kadi murtil Tan samar ingah kawula/ Sumangga atêluk marko/ dhumatêng Bêthara Rama/ kawula kuwawal déné dene mêsahipun/ amungsuh kêlawan déwall (Pupuh Asmarandhana-Gatra kaping 107) \\ Terjemahan: \\ //Nyata pastilah sebuah badan/ Tidaklah samar untuk saya rawat/ Silakan singkirkan diri/ Kepada Bethara Rama/ Saya kuat/ Datanglah musuh/ Musuh melawan Dewa// (Tembang Asmarandhana-Baris ke 107)}

Petikan diatas menunjukkab bahwa kegigihan Kumbakarna sudah tidak diragukan lagi. Kumbakarna tetap bersikeras untuk menguatkan dan mengatakan betapa dirinya ini memanglah bisa menjalaninya. Ia tak peduli berapapun dan siapapun lawan perangnya. Hal ini tetap dia lakukan untuk menjaga keutuhan negara kecintaannya Ngalengka tersebut. Memang seorang pejuang apapun rintangan jika suatu pejuang maka tetaplah dia akan menjadi pejuang. Hal lain juga ditunjukkan melalui cuplikan data di bawah ini:

\section{//Dasamuka angandika aris/ éh ta pata githok punika/ ana dén prajurita/ Dasamuka seru muwus/ Bibisana lamun ambalik/ kumbakarna tapa/ purwané Sang Prabu/ nimbali buta prawiral/ (Pupuh Dhandhanggula-Gatra kaping 125) \\ Terjemahan: \\ //Dasamuka berkata pelan/Eh benarkanlah ini leherku/ Berhati-hatilah ada prajurit/ Dasamuka berkata dengan menutup matanya/ Jika Bibisana kembali/ Kumbakarna kemudian bertapa/ Berawal dari sang Prabu/ Berani mengundang buta// (Tembang Dhandhanggula-Baris ke 125)}

Cuplikan data di atas menunjukkan bahwa keberanian sang Kumbakarna yang berani berbicara dengan siapapun. Kala itu Dasamuka atau Rahwana sedang meminta untuk tetap berhatihati kepada adiknya Kumbakarna itu. Kala ada prajurit datang tetaplah dia meminta untuk menyiapkan strategi perangnya. Jangan sampai dia hanya bisa berdiam diri tanpa adanya usaha. Kemudian Rahwana kembali melakukan dengan cara mengintip prajurit tersebut. Prajurit tersebut tidak lain adalah utusan dari Sang Rama. Dia menyuruh jikalau sang Bibisana kembali maka ia harus sesegera mungkin agar tetap memantapkan niatnya untuk tetap berdiri tegak tanpa adanya halangan suatu apapun. Akhirna sang Kumbakarna berdiam bertapa meinta lindungan kepada sang Dewa. Tidak lama kemudian hingga akhirnya Sang Prabu Rama dan juga pasukannya tersebut datang. Kumbakarna sang pejuang hebat, meskipun Kumbakarna ini adalah seseorang atau raksasa yang kuat tetapi Kumbakarna adalah raksasa yang buta. Memanglah demikian banyak kisah perjuangan Sang Kumbakarna ini, ada beberapa rintangan yang dia lalui. Hanya karena dia ingin menyelamatkan negara tercintanya yakni Ngalengka, ia rela dianggap membela Rahwana yang 
bersikap bodoh. Kumbakarna juga rela dia harus kehilangan rasa terhadap adiknya Bibisana. Kumbakarna pada saat itu juga sudah sesering mungkin mengingatkan kepada kakanya Rahwana akan ketidakpatutan sikap yang dilakukan oleh Rahwana atau Dasamuka itu. Dengan alasan karena Bibisana dan Kumbakarna ini berbeda pendapat. Sehingga timbullah seperti perang saudara tersebut. Berikut ini adalah beberapa petikan yang menunjukkan atas kekuatannya ketika berhadapan dengan lawan:

\begin{abstract}
//Anggera ki kumbakarna/ Ngamuk riwut riwonda akéh kang mati/ Bahu kering mêksih ngamuk/ Lêsmana sigra anyipat/ Wus lumêpas ki panah sigra cumundhuk/ Bahunê ki kumbakarna kiri tugel guling lanting// (Pupuh Sinom-Gatra kaping 124) Terjemahan:

//Ki kumbakarna selalu/ Riwonda mengamuk banyak yang mati/ Bahunya yang tua masih tetap mengamuk/ lesmana kemudian mengetahui dengan sendirinya/ Sudahlah terlepas panah kemudian mengenai sasarannya/ Bahunya kumbakarna patah sangat ia mengacungkan tangan// (Tembang Sinom-Baris ke 124)
\end{abstract}

Hal ini menjadi dasar yang kuat mengenai kuatnya sang Kumbakarna. Meskipun badannya sudah terkena panah, dia tetap kuat dan maju melawan apa yang di depannya sekarang. Semangat juang yang tinggi menjadikan Kumbakarna semakin dipenuhi dengan keyakinan bahwa tidak ada yang tidak mungkin selama Kumbakarna mau berjuang sekuat tenaga.

\title{
Kumbakarna tetap menerima pemberian Sang Dewa meskipun dianugerahi kebiasaan tidur yang melampaui batasan
}

Tidak hanya hal baik-baiknya saja, dalam sosok ataupun diri sang Kumbakarna ini memiliki keunikan tersendiri. Hal ini dapat dilihat melalui sebuah kisahnya yakni kebiasaan tidur lama pada sosok Kumbakarna. Kumbakarna ketika tidur selalu berjam-jam dan bahkan ada beberapa versi yang menceritakan bahwa Kumbakanrna tertidur dengan jangka waktu enam bulan. Demikian jika bangun juga dalam wktu yang enam bulan. Anugrah tidur ini berawal dari ucapan yang seharusnya berbunyai "Supta Sada" yang Berikut ini adalah beberapa cuplikan data yang menunjukkan atas hal yang aneh pada sosok Kumbakarna:

\begin{abstract}
//Ki Arya Kumbakarna/ Nora obah nora owah/ Méksih eca-eca nendra/ Ana buta kaki-kakil Mecrohi sajroning sun/ Méksih eca-eca nendra/ Kumbakarna Gusti mami/ Negarane ngalengka iki bêdhah// (Pupuh Sinom-Gatra kaping 105)

Terjemahan:

// Ki Arya Kumbakarna/ Tidak bergerak dan tidak berubah/ Masih terlihat tertidur / Ada buta yang sudah tua/ Mengajak berkelahi di dalam hatinya/ Masih terlihat tertidur / Kumbakarna Gustiku/ Negara Ngalengka sedang berada dalam serangan musuh// (Tembang Sinom-Baris ke-105)
\end{abstract}

Cuplikan data tersebut menunjukkan bahwa Kumbakarna masih sulit untuk dibangunkan dari lelap tidurnya. Hal yang membuat Kumbakarna suka tertidur adalah adanya kekeliruan dalam mengucap "Saka Suda" yang artinya adalah selalu bahagia, selalu senang. Akan tetapi pada penyembahannya terhadap Dewa Brahmana ini malah keliru dalam pengucapannya itu, Kumbakarna malah mengucapkan "Supta Sada". Tidak lain hal ini dikarenakan karena Kumbakarna adalah seekor raksasa besar sehingga secara tidak diketahui Saraswati membelokkan lidah sang Kumbakarna hingga akhirnya kala itu Kumbakarna diberika anugrah oleh sang Dewa berupa tidur yang sangat lama. Akan tetapi ada beberapa hikmah yang didapatkan ketika Kumbakarna ini adalah suka tidur, yakni bisa mengurangi hawa nafsunya (Wawancara dengan Bapak Sono, 62 Tahun). Maksudnya adalah ketika raksasa besar yang kala itu selalu senang dan 
selalu bahagia pasti Kumbakarna akan menjadi bergairah dan jauh lebih senang untuk mengumbar hawa nafsunya. Akan tetapi karena kecerdasan Dewi Saraswati pada saat membengkokkan lidah sang Kumbakarna akhirnya sang Kumbakarna tidak memperoleh anugrah berupa kebahagiaan namun anugerah berupa kebiasaan tidur selama enam bulan dan bangun juga dalam enam bulan. Sehingga dari kebiasaannya itu negara Ngalengka tetap damai dan tidak ada unsur kacau balau dan taka da gelora nafsu kala itu. Kumbakrna saat itu dibangunkan agar bisa membela negara Ngalengka. Kala itu Kumbakarna juga sedang berhadapan dengan seekor raksasa lainnya :

\begin{abstract}
//Patih Prasta sampun pêjah/ Para putra wus ngemasi/Sapa ingkang maju ngrana/ Buta tuwa amarani/ Kumbakanra pasti tangi/ Nora obah nora sêgu/ Buta tuwa sigra nyandhak/ Dakare Ki Arya Ki/ Gya nedha ati ngikibi Kumbakarnal/ (Pupuh Sinom-Gatra kaping 106)

Terjemahan:

//Patih Prasta sudah meninggal / Para putra sudah meninggal/ Siapa yang kan maju ke medan perang/ Buta tua yang menghampiri/ Kumbakarna pasti akan terbangun/ Tidak bergerak tidak bersuara/ Buta tua yang mengenggamnya/ Yang sewenangwenang arya ini/ Kemudian memakan hati dengan dengan cara (ora blaka) Kumbakarna.// (Tembang Sinom-Baris ke-106)
\end{abstract}

Kala itu negara Ngalengka sangat kebingungan karena sangat membutuhkan sang Kumbakarna. Hal ini karena Kumbakarna terlanjur tidur terlalu sedangkan keadaan Ngalengka masih sangat kacau balau apalagi keadaan Patih Prasta dan para putranya yang sudah meninggalkan negara Ngalengka. Kemudian seekor buta segera menghampiri sambil mengatakan bahwa Kumbakarna akan segera bangun dan membela keutuhan negara Ngalengka ini. Tak lama kemudian buta tersebut membujuk agar Kumbakarna segera bangun (Bapak Sono, Dhalang 68 Tahun). Banyak sekali hal yang dapat dipetik atas anehnya Kumbakarna dalam anugrah tdurnya ini, Selain dapat menyelamatkan negara Ngalengka ia juga bisa menyelamatkan dirinya sebagai raksasa yang gagah perkasa.

\title{
Usaha Kumbakarna yang rela berkorban di medan perang
}

Hal lain yang menjadikan Kumbakarna pantas untuk diangkat dalam penelitian ini adalah sifat dan perilakunya yang kala itu dianggap sudah gugur di medan perang akan tetapi dia tetap membangkitkan dirinya itu dengan penuh semangat yang tinggi. Dia tidak akan berhenti berjuang sebelum maut mengatakan waktunya dia kembali. Selama Kumbakarna maish bernyawa apapun akan tetap dia lakukan demi menyelamatkan negara ngalengka. Beikut ini adalah bukti bahwa Kumbakarna di kala itu yang hampir saja gugur kemudian dia tetap berdiri tegak membela Ngalengka adalah sebagai berikut:

//Karna kang winarna/ Iya Arya Kumbakarna/ Mêksih eca-eca gunging/ Mênyang pasareyan Jawi/ Dhadhag kawusa seng dhem situ/Giris wadya dhangka/Katon wus rinekat/Wus kinepung kedhaton ing dhat duka/l (Pupuh Sinom-Gatra kaping 104) Terjemahan:

//Karna yang telah diceritakan/ Iya itu Arya Kumbakarna/ Masih terlihat untuk diberanikan/ Menuju ke makam Jawa/ Tetap menjaga untuk menuju sebuah wadah air yang besar (jugangan)/ Prajurit yang menakutkan berada pada pembuangan mayat/ Terlihat sudah dibersihkan/ Sudah dikepung pada keraton yang cukup berduka// (Tembang Sinom- Baris ke-104)

Meskipun dikabarkan Karna telah kalah Kumbakarna tetap memberanikan diri. Kala itu Karna menuju ke makam Jawa. Dia menuju sebuah sumber air yang sangat besar untuk 
membersihkan dirinya. Padahal ia tahu di makam tersebut ada prajurit menaktukan sebagai penjaga sekaligus penunggu dalam pembuangan mayat. Kumbakarna tidak menghiraukan akan hal itu. Dia percaya bahwa suatu hal yang tetap membuatnya kukuh adalah ia ingin tetap menyelamatkan negeri Ngalengka itu. Dengan sangat berhati-hati akhirnya Kumbakarna terlihat untuk di kepung menu kedaton yang saat itu sedang dalam keadaan duka. Kumbakarna memang terlihat berbeda dengan Rahwana. Rahwana hanya memikirkan kepentingan individunya saja. Ia tidak hirau apakah dengan perilaku menculik Sita itu bisa membawa dampak negative terhadap negaranya atau tidak ia tetap tidak peduli. Dia hanya mementingkan akan kepuasan batiniah saja. Bahkan Kumbakarna yang telah berani dan berjuang mati-matian membela Ngalengka. Tidak hanya itu, akan tetapi ada hal menarik tetapi juga diangap sebagai suatu hal yang agak meresahkan dari suatu Kumbakarna adalah dia mau melakukan tapabrata yang dilakukannya selama bertahuntahun (Ariani, 2013:96). Dia meminta kepada sang Dewa akan apa yang ia harapkan terhadap keutuhan Ngalengka. Memang ada beberapa versi yang menceritakan bahwa awalnya Kumbakarna tidak mau melakukan perlawanannya terhadap Sri Rama. Menurutnya semua adalah kesalahan dari kakanya yakni Rahwana sendiri.

Mustahil sebenarnya bagi sang Kumbakarna harus melawan prabu yang terkenal dengan kesetiaan, kejujuran, dan kekuatannya itu. Bahkan Kumbakarna juga sempat mengucapkan bahwa menurut Kumbakarna, Rahwana adalah sosok ratu yang tidak bisa mengayomi rakyat-rakyatnya yang ada di negara Ngalengka. Dia hanya mementingkan perasaan dan hawa nafsunya saja. Akan tetapi, karena memang Rahwana ini dikenal sebaai sosok yang cerdik, ada saja perilakunya agar membuat adiknya Kumbakarna ini mau melawan Sang Rama dan mau membelanya. Rahwana ini melalukan suatu upaya dengan cara memberikan hal-hal yang berbau sugesti atau bisa diangap sebagai usaha memanas-manaso Kumbakarna agar mau dan berani lemawan Prabu Rama. Memang Rahwana tidak pernah kehabisan akal. Rahwana menceritakan kepada Kumbakarna bahwa pada saat itu anaknya yang bernama Kumba-kumba dan Aswani Kumba sudah gugur di medan perang membela negara Ngalengka. Berikut ini adalah beberapa cuplikan data yang sesuai dengan cerita tersebut :

\section{//Bêdhes kutu sigra mangsah/Yuta wendra kutu samya den buki/Kumbakarna rubuh/Gêro- gêro kumbakarna/ Gya kinosoki bahu mati rongéwu/Lir gajah dén rubung tuma/ Wulu siji bêdhés siji// (Pupuh Sinom-Gatra kaping 120) \\ Terjemahan: \\ //Anjing kutu lalu memangsanya/ Sejuta ikan laut dan kutu yang sudah tua/ Kumbakarna jatuh/ Kumbakarna menangis/ Kemudian membersihkan bahu yang mati sebanyak dua ribu/ Seperti gajah yang dihinggapi kutu/Bulu satu monyet satu// (Tembang Sinom-Baris ke-120)}

Kala itu Kumbakarna sudah seperti bangkai yang terlihat. Sejuta kawanan pasukan serta prajurit dari Prabu Rama sudah menghabiskan sang senapati Kumbakarna ini. Bagaikan suatu yang tidak berguna lagi. Semua nampak usai kala itu. Kumbakarna dengan segala bersikerasnya untuk membela negara Ngalengka hanya cukup dalam medan pertempuran. Tak hanya itu, Kumbakarna juga berjuang mati-matian dengan segala kemampuan. Tubuhnya yang dihinggapi oleh banyak kutu menjadikannya semakin tersiksa. Selain itu ada beberapa cuplikan lain yang menunjukkan betapa mengenasnya akan sosok Kumbakarna dalam mencapai kemenangan negara Ngalengka :

//Glundhung sang Kumbakarna/ Meksih ngamuk kathah gembung puniki/ Riwonda kathah ki lampus/ Sang bethara sing nyandhak/ Ardhali kang panah sigra cumundhuk/Gulune sang kumbakarna/ Babar wisan gya punikall (Pupuh SinomGatra kaping 125)

Terjemahan: 
//Kumbakarna jatuh/ Masih mengamuk dan banyak macan buas/ Banyak pasukan kera yang mati/ Sang bethara yang memegangnya/ Panah yang menitiskan akan kenafsuannya/Lehernya Kumbakarna/ kemudian tamatlah semuanya// (Tembang Sinom-Baris ke -125 .

Hal tersebut menunjukkan bahwa Kumbakarna berjuang mati-matian merebut kejayaan. Akan tetapi sang penguasa bumi berkehendak lain. Apalagi Pasukan Prabu Ramawijaya sangatlah banyak, sedangkan Kumbakarna sendirian tanpa prajurit tanpa bantuan dari kakanya Rahwana sekalipun. Alkisah Kumbakarna mati di tangan Prabu Rama.

\section{Relevansi watak tokoh Kumbakarna dalam Serat Ramawijaya sebagai refleksi semangat patriotisme pada pemuda Indonesia}

Setelah kita mengetahui apa saja yang telah kita bahasa mengenai Tokoh Kumbakarna, selanjutnya adalah mengaitkan dengan semangat patriotism pemuda di Indonesia. Patriotisme sendiri adalah suatu keadaan cinta terhadap tanah air dengan segala semangat membara yang ada pada diri seseorang. Hasnita dan Haizam (2011:22-34) menyatakan bahwa kesanggupan akan berpatriotisme ini merupakan proses sepanjang hayat, maka perlu konsistensi yang tinggi untuk menjalankannya. Patriotisme hadir atas adanya jiwa jiwa patriotic dengan pemahaman bangsa dan nasionalisme (Bakry, 2010:145). Sesuai dengan pendapat ahli tersebut yakni alasan utama memilih patriotisme ini tentunya ada kaitannya dengan watak tokoh Kumbakarna. Berikut ini adalah beberapa uraian mengenai relevansi Kumbakarna sebagai tefleksi semangat patriotisme pemuda di Indonesia:

\section{Membangkitkan sikap persatuan dan bela negara pada pemuda Indonesia}

Setelah kita ketahui cerita Kumbakarna dalam semangatnya membela negara Ngalengka tentu hal ini dapat menjadi refleksi besar bagi para pemuda Indonesia untuk bisa meniru keteladanan semangat bela negara. Jika sikap persatuan tersebut ditanamkan dengan benar pasti akan tumbuh dalam kehidupan berbangsa dan bernegara. Bela negara sendiri diartikan sebagai suatu proses dimana seseorang melakukan sesuatu dan tanpa pamrih mencintai negaranya. Bela negara sendiri merupakan sikap yang seharusnya dimiliki oleh tiap-tiap warga negara agar terhindar dari sebuah ancaman (Winarno, 2013:182). Melalui sikap bela negara sendiri juga dijelaskan adanya kepentingan nasional sebisa mungkin bisa menyadarkan dalam nilai-nilai demokrasi, kebebasan berpendapat, dan tentunya akan hak asasi manusia (Dover \& Phythian, 2011:420-444). Memang benar bahwa bela negara adalah suatu hal yang diawali dari kepribadian seseorang yang berjiwa semangat besar. Apalagi zaman sekarang sudah memasuki teknologi yang serba canggih. Semuanya dapat diakses dimanapun dan kapanpun seseorang berada. Hal utama adalah mudahnya pengaruh beperilaku seperti apa yang idolakan atau lebih tepatnya adalah perilaku ingin menjadi warga negara lain daripada mempertahankan negara Indonesia sendiri. Melalui refleksi tokoh Kumbakarna ini akan menambah semangat patriotisme pada pemuda di Indonesia. Berikut adalah beberapa pertanyaan yang diajukan mengenai relvansi tokoh Kumbakarna dalam Serat Ramawijaya dengan semangat patriotisme pemuda:

Tabel 1. Pertanyaan Pemahaman Patriotisme

\begin{tabular}{|l|l|}
\hline No & Pertanyaan \\
\hline 1. & $\begin{array}{l}\text { Apakah sikap pemuda di Indonesia saat ini sudah memiliki semangat } \\
\text { patriotisme yang tinggi? }\end{array}$ \\
\hline 2. & $\begin{array}{l}\text { Apakah pemuda Indonesia saat ini mengetahui sosok Kumbakarna dengan } \\
\text { sikap patriotisme dan kesabaran yang tinggi sebagai senapati dalam Serat } \\
\text { Ramawijaya? }\end{array}$ \\
\hline
\end{tabular}




\begin{tabular}{|l|l|}
\hline 3. & $\begin{array}{l}\text { Bagaimana relevansi semangat juang tokoh Kumbakarna dengan semangat } \\
\text { patriotisme pemuda saat ini ? }\end{array}$ \\
\hline 4. & $\begin{array}{l}\text { Bagaimana etos kerja pemuda Indonesia dalam menghadapi kemajuan } \\
\text { zaman? }\end{array}$ \\
\hline
\end{tabular}

Berikut ini adalah hasil angket sejumlah 40 responden dari berbagai kalangan pemuda tentang semangat patriotisme pemuda yang ada di Indonesia:

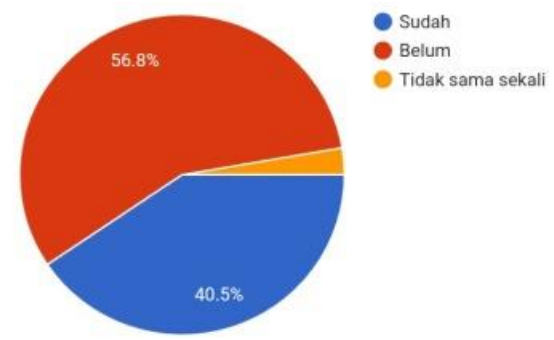

Gambar 1. Pendapat pemuda tentang sikap patriotisme di Indonesia

Data di atas menunjukkan bahwa terdapat berbagai macam jawaban setelah ditanyai megenai penerapan sikap patriotisme yang ada di negara Indonesia. 56,8\% menyatakan bahwa menurutnya sikap patriotisme di Indonesia ini belum banyak ditemukan di berbagai daerah. Pemuda saat ini cenderung memiliki sikap yang acuh dan tidak mau tahu akan keutuhan suatu negara. Hal ini dapat dibuktikan dari hal kecil misalnya saat ini pemuda lebih sering memghabiskan waktunya untuk ikut-ikutan trend and style yang ada di luar negeri. Mereka tidak bangga dengan apa yang ada di negara ini. Hal lain juga bisa ditemukan misalnya kebiasaan dalam berbahasa. Bukan berati bahasa asing adalah bahasa yang harus dikuasi dengan benar, akan tetapi sebagai warga negara yang baik kita juga harus menyeimbangkan antara kemampuan berbahasa sesuai dengan bahasa Indonesia sendiri serta kemampuan kita untuk bisa berbahasa asing.

Kemudian dari $40,5 \%$ pemuda menjawab sudah ada semangat patriotisme yang tumbuh di negara Indonesia kita ini. Hal ini dapat diwujudkan misalanya melalui akun ataupun media-media sosial pemuda sering menggunakan atau bahkan sering mengunjungi tempat-tempat di berbagai daerah untuk menunjukkan bahwa itulah keanekaragaman yang ada di Indonsia. Mereka dengan bangga menggunakan baju adat untuk dipajang di media sosial, ada juga yang menggunakan spotspot foto dan tempat bersejarah misalnya mengunjungi candi, museum, dan tempat sejarah lainnya untuk mereka jadikan ajang berlomba ria menunjukkan kekhasan negaranya. Bagi mereka itu adalah salah satu wujud bela negara. Hal lain juga dapat ditemukan ketika berdemokrasi, tidak sedikit pemuda di Indonesia yang sangat suka ketika ditanya mengenai apa itu birokrasi, apa itu demokrasi, apa itu keutuhan negara.

Hasil presentasi terakhir yakni sejumlah $2,7 \%$ pemuda di Indonesia tidak menerapkan semangat patriostime sebagaimana mestinya. Menurutnya hal ini nampak sekali dari kebiasaan pemuda yang lebih dan sangat sering menerapkan sikap plagiarism dalam unsur berkarya. Banyak sekali kebiasaan plagiasi ini ditemukan di kalangan pemuda. Apalagi media internet yang memberikan contoh mengenai suatu karya sudah banyak. Bagi pemuda yang malas dalam beride an berkreativitas mereka lebih senang akan adanya sikap untuk plagiat tersebut. Dewi Rahma Andhani (21Tahun) mengatakan bahwa terkadang ia juga menerapkan sikap plagiasi ini dalam kehiupannya. Ketika ia sudah tidak ada lagi ide untuk berfikir menurutnya membuka internet dan mengcopy-paste adalah hal yang menyelamatkan dirinya untuk memenuhi kebutuhan. Melalui penjelasan tentang relevansi tokoh Kumbakarna dalam kehidupan sehari-hari di kalangan pemuda dengan aturan yang sesuai nantinya akan menjadikan pemuda-pemuda di Indonesia ini menjadi pemuda harapan bangsa yang bisa mengharumkan nama negara di seluruh dunia. 


\section{Mendorong pemuda Indonesia untuk sabar dalam menggapai tujuan dan cita-cita bangsa}

Sikap sabar menunjukkan suatu hal yang dilandasi atas keikhlasan hati mencapai kebutuhan suatu negara. Salah satu teori kesabaran menyebutkan bahwa definisi sabar sendiri merupakan kemampuan untuk mengatur dan mengendalikan suatu pikiran dan perasaan (Yusuf, 2010:98). Sabar juga didasari atas keinginan dari dalam seseorang yang nantinya akan mencapai tujuan dari pencapaian. Hilgard dalam Slameto (2010:57) menyebutkan bahwa keinginan merupakan bagian dari minat "Intersest is persisting tendency to pay attention to and enjoy some activity and content" dengan artian ketika sesorang memiliki minat atau keinginan maka seseorang akan cenderung memeperhatikan kegiatan yang akan dilakukannya. Sesuai dengan apa yang dikatakan oleh kedua ahli tersebut bahwa sikap sabar adalah bagian dari dorongan minat, dan hal ini direlevansikan pada tokoh Kumbakarna dalam Serat Ramawijaya sebagai refleksi semangat patriotisme ini adalah kesabaran yang digunakan Kumbakarna ketika ia dihadang bahkan sampai meninggal dunia untuk berperang dengan musuh dari kawanan Prabu Ramawijaya. Sikap sabar yang ada pada tokoh Kumbakarna ini dianggap sebagi suatu keunikan sendiri.

Hal ini dikarenakan Kumbakarna adalah raksasa besar, dia memiliki kapasitas tidur yang tidak umunya yakni selama enam bulan ia baru bisa terbangun. Namun karena itu pemberian Sang Dewa ia tetap sabar dan menerima. Apalagi sebagai seorang senapati di negara Ngalengka ia harus benar-benar menerapkan semangat patriotisme itu sendiri di dirinya terlebih dahulu dan barulah kemudian ia bisa membela negara Ngalengka dari serangan lawan. Mengenai cerita Kumbakarna sendiri mungkin ada beberapa pemuda di Indonesia yang belum mengetahui tentang relevansinya dengan kesabaran yang ada pada pemuda saat ini. Padahal kesabaran Kumbakarna ini sangatlah memiliki peran besar hingga akhirnya Kumbakarna dikenal sebagai pejuang tangguh yang harus dimaki menjadi pembela kebatilan karena dianggap membela perilaku tidak terpuji yang dilakukan oleh kakanya yakni Rahwana. Untuk mengetahui sejauh mana pengetahuan pemuda mengenai relevansi kesabaran yang ada pada Kumbakarna sebagai refleksi semangat pemuda Indonesia. Berikut ini hasil angket tentang pemahaman pemuda tentang kesabaran Kumbakarna :

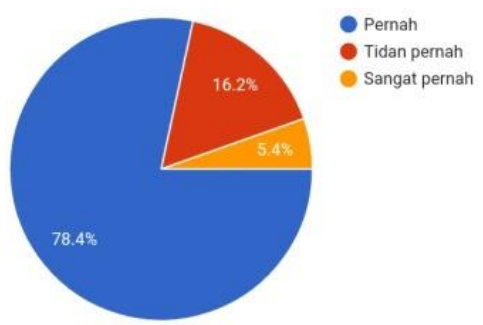

Gambar 2. Pemahaman pemuda Indonesia tentang kesabaran pada tokoh Kumbakarna

Diagram diatas menunjukkan bahwa ada 78,4 \% yang mengatakan bahwa pemuda Indonesia pernah membaca dan mengetahui apa yang menjadi kesabaran dari Kumbakarna. Menurut hasil tersebut dapat ditemukan bahwa Pemuda saat ini masih pernah melihat dan mengetahui seperti apa cerita tersebut. Kumbakarna sosok pejuang tangguh yang terkenal dengan jiwa nasional dan kesabarannya dalam menghadapi lawan. Kumbakarna bisa mengatasinya sendiri dengan keikhlasan hatinya meskipun berakhir keguguran yang tidak disangka-sangka. Keprawiraaannya dikenal seluruh jagat Ngalengka. Berhati tulus, setia adalah simbol dari Kumbakarna. Bahkan karena kesabarannya ini dia diberi julukan sang Arya Kumbakarna. Arya sendiri adalah suatu sebutan untuk para leluhur. Maka dari itu Kumbakarna juga dinobatkan sang senapati. Menurut pemuda yang mengatakan pernah ini Kumbakarna sangatlah memiliki refleksi yang sangat berdampak positif.

Data responden lainnya yakni sebanyak $16,2 \%$ menyatakan bahwa mereka tidak pernah melihat dan mendengar apa saja ketulusan dan kesabaran yang ada pada tokoh Kumbakarna. Menurut mereka melihat dan membaca cerita lain jauh lebih menyenangkan. Menurutnya tidak 
semua orang suka dengan cerita yang berabu budaya. Apalagi saat ini cerita berbasis audio visual di berbagai media sosial juga sudah ada. Hal ini tentu perlu dipertanyakan, apakah ada unsur lain yang mendasari anak muda tersebut tidak suka dengan cerita Ramayana utamanya pada tokoh Kumbakarna, atau justru tidak suka sama sekali dengan gaya bercerita dari sebuah cerita epos tersebut. Melalui poin ini sangat diharapkan sekali relevansi kesabaran Kumbakarna dalam Serat Ramawijaya bisa menjadi refleksi dalam kehidupan sehari-hari anak muda di Indonesia. Dengan begitu ketika anak muda ingin menjunjung tinggi negaranya, ingin mengharumkan negaranya harus benar-benar dengan proses yang sangat keras. Tidak hanya usaha saja tapi juga berdoa kepada Tuhan Yang Maha Esa.

Hal terakhir adalah adanya data yang menunjukkan sebanyak 5,4 \% mengatakan bahwa pemuda Indonesia sangat pernah mendengar dan mengetahui bagaimana cerita sang Kumbakarna sosok raksasa namun penuh kesabaran. Menurut pendapat pemuda yang mengatakan sangat pernah ini percaya bahwa melalui cerita ataupun epos yang berbasis budaya khususnya budaya Jawa ini sangat memberikan pengaruh yang besar terhadap perilaku kehidupan pemuda di Indonesia. Silvia Hartanti Putri(18 Tahun) mengatakan bahwa sudah semestinya sebagai orang yang lahir di Indonesia khususnya saya yang berasal dari suku Jawa ini cinta terhadap cerita epos Ramayana, apalagi melalui tokoh Kumbakarna ini menurut tokoh yang dipenuhi dengan hal yang seharusnya memang dicontoh. Menurunya sebenarnya tidak pemuda di Indonesia yang berasal dari suku Jawa saja, sebisa mungkin sebagai pemuda yang benar-benar Indonesia kita juga mencintai segala karya di seluruh daerah. Poin kedua ini memang sangat dibutuhkan dalam menanamkan sifat kesabaran dan mengurangi hawa nafsu berupa kemalasan pada Pemuda. Ingat kata Bung Karno yakni JASMERAH yang artinya Jangan sesekali kita melupakan sejarah. Tidak ada salahnya jika kita menjadikan pelajaran sejarah ini menjadi pelajaran yang membawa kita berkaca di masa lalu untuk menemui kebaikan dan kesuksesan di masa depan. Dapat dikatakan melalui refleksi kesabaran sang Kumbakarna ini diharapkan pemuda di seluruh Indonesia bisa menata kehidupan yang menurutnya sekarang ini kurang baik agar kedepannya menjadi sesuatu dan sikap yang jauh lebih baik.

\section{Memberikan keteladanan bagi pemuda Indonesia dalam sikap mengormati dan menghargai sesorang tanpa membedakan ras, suku, dan budaya}

Pelajaran yang dapat dipetik dari tokoh Kumbakarna dalam Serat Ramawijaya ini tidak hanya dari segi bela negara, persatuan, maupun kesabarannya saja. Tokoh Kumbakarna ini juga terkenal sebaga tokoh yang menjaga dan menghormati paduka atau mungkin lebih dari dirinya dan ataupun lebih rendah (kasta dalam kerajaan). Dapat dilihat dari sikap yang mengutamakan orang lain daripada diri sendiri. Bahkan sekalipun Kumbakarna tetap diam ketika ia diejek oleh prajurit dari Sri Rama. Sikap menghargai adalah keadaaan dimana seorang individu harus mengindahkan dan memuliakan serta sikap yang berupa menjunjung tinggi orang lain (Elfindri, 2012:101). Keteladanan berupa menghargai seseorang juga merupakan bagian dari etika moral dan kesopanan. Peran kesopanan dari adanya sikap menghargai ini memiliki keterkaitan karena kesopanan adalah upaya mengahrgai hubungan dengan baik antar perorangan (Sukarno, 2010:60). Sesuai dengan pendapat dari ahli tersebut mengenai poin ini yakni sikap hormat pada tokoh Kumbakarna jika dikaitkan dengan sikap menghormati pada pemuda Indonesia tentu adalah hal yang menarik untuk diperbincangkan. Berikut ini adalah petikan hasil wawancara mengenai sikap menghormati yang dilakukan oleh pemuda saat ini:

Tabel 2. Hasil wawancara mengenai sikap hormat pemuda di Indonesia

\begin{tabular}{|c|l|l|}
\hline No. & \multicolumn{1}{|c|}{ Nama/Usia } & \multicolumn{1}{c|}{ Hasil wawancara } \\
\hline 1 & $\begin{array}{l}\text { Arina Setya } \\
\text { Hernawati/14Tahun }\end{array}$ & $\begin{array}{l}\text { Sikap hormat menurutnya adalah hal yang } \\
\text { tidak perlu banyak kata tetapi lebih } \\
\text { menekankan pada tindakan nyata }\end{array}$ \\
\hline
\end{tabular}




\begin{tabular}{|c|l|l|}
\hline 2 & $\begin{array}{l}\text { Deddy Kusuma } \\
\text { Wardhana/20 Tahun }\end{array}$ & $\begin{array}{l}\text { Sejatinya orang menghormati tidak hanya } \\
\text { hormat yang bersifat dari lahir saja tetapi } \\
\text { harus ditekankan pada hormat dari } \\
\text { batiniahnya }\end{array}$ \\
\hline 3 & Dessy Saraswati/28 Tahun & $\begin{array}{l}\text { Penghormatan lebih mengarah kepada } \\
\text { bagaimana seseorang memperlakukan dari } \\
\text { sikap dan tindakan tanpa harus dilihat } \\
\text { orang lain terlebih dahulu }\end{array}$ \\
\hline 3 & $\begin{array}{l}\text { Muhammad Sailendra } \\
\text { Abimanyu/15 Tahun }\end{array}$ & $\begin{array}{l}\text { Bentuk hormat adalah kita harus taat dan } \\
\text { beradab terhadap siapapun }\end{array}$ \\
\hline 4 & $\begin{array}{l}\text { Mei Rindiani Kusuma } \\
\text { Dewi/21 Tahun }\end{array}$ & $\begin{array}{l}\text { Menghormati aalah suatu kewajian } \\
\text { manusia. Jika seseorang ingin dihormati } \\
\text { maka hormatilah siapapun }\end{array}$ \\
\hline 5 & Sukengsi/32 Tahun & $\begin{array}{l}\text { Berusaha menghormati adalah sikap yang } \\
\text { harusnya diterapkan pada anak muda } \\
\text { mulai dia lahir agar nantinya dapat dan } \\
\text { mampu menjadi manusia yang bisa } \\
\text { menghormati orang lain }\end{array}$ \\
\hline 6 & Meyko Lestyanto/12 Tahun & $\begin{array}{l}\text { Hormat adalah sikap yang taat dan tidak } \\
\text { semena-mena terhadap orang lain }\end{array}$ \\
\hline 7 & $\begin{array}{l}\text { Kusuma Candra } \\
\text { Prasetyoningtyas/18 Tahun }\end{array}$ & $\begin{array}{l}\text { Perilaku yang berwujud hormat adalah } \\
\text { bisa toleransi terhadap siapapun }\end{array}$ \\
\hline
\end{tabular}

Setelah kita ketahui data di atas tentu kita berfikir bahwa sikap menghormati memang tudaklah mudah. Terlebih jika menghormati terhadap orang yang tidak dikenal tentu sangatlah sulit. Kehidupan saat ini adalah kehidupan yang berlomba-lomba menuju kebaikan bukan berlomba-lomba untuk keburukan. Melalui relvansi sikap dari tokoh Kumbakarna dalam Serat Ramawijaya ini diharapkan pemuda di Indonesia bisa menerapkan sikap menghormati sekalipun dengan orang yang pernah membencinya, dengan orang yang pernah menyakitinya, dan dengan siapapun. Seperti apa yang telah Kumbakarna lakukan, dia tidak dengki dan tidak membalas apa yang telah Dasamuka katakana bahwa dia adalah sosok yang tidak jauh dari sosok Rahwana, kejam dan sangat licik. Dengan demikian sikap patriotisme tidak hanya dari bela negaa saja tetapi sikap patriotisme ini bisa dilakukan melalui suatu penghormatan dan menghargai orang lain.

\section{Menjadikan pemuda Indonesia sebagai pribadi yang selalu bekerja keras dan tidak mudah puas akan pencapaian baik pencapaian untuk diri maupun untuk mengharumkan bangsa Indonesia}

Poin yang tidak kalah pentingnya dalam relevansi pada tokoh Kumbakarna sebagai refleksi semangat patriotisme di Indonesia ini adalah kerja keras, dan tidak mudah putus asa melawan panglima perang beserta jajaran prajurit Ramawijaya. Keteguhannya meskipun sudah hampir gugur kala itu bahkan sudah dipanah berkali-kali namun tetap berusaha kuat dalam membela negara Ngalengka. Kerja keras adalah suatu usaha yang dilalui dengan rasa dan kegigihan serta kesungguhan dalam mengatasi hambatan yang ada sereta tidak kenal putus asa (Mustari, 2011:51). Sedangkan menurut Gunawan (2012:33) kerja keras adalah bekerja dengan cara yang sungguhsungguh. Sesuai dengan apa yang telah dikatakan oleh para ahli tersebut bahwa kerja keras adalah berawal dari diri sendiri. Meskipun seseorang dimotivasi oleh orang lain tetapi jika seseorang itu belum bisa memberikan motivasi terhadap dirinya sendiri sama sajalah sikap penanaman kerja keras tersebut. Sesuai dengan poin pembahasan ini. Tentunya tokoh Kumbakarna juga memiliki peranan yang besar terhadap refleksi kesabaran yang nantinya akan diterapkan oleh pemuda di Indonesia dalam mengharumkan nama bangsa . Dalam Penelitian ini peneliti juga mengadakan 
angket yang menunjukkan bahwa adanya perbedaan terhadap semangat dalam berkarya pada masing-masing individu. Untuk lebih jelasnya berikut adalah diagram yang menunjkukkan tingkat perbedaan kerja keras pada pemuda di Indonesia :

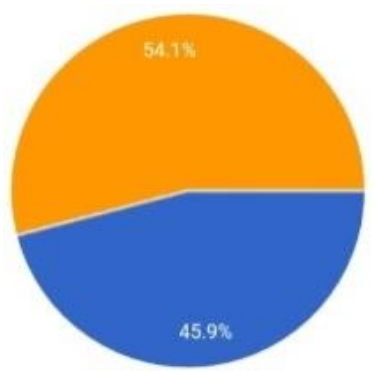

Gambar 3. Grafik perbedaan kerja keras pemuda di Indonesia

Data gambar di atas menunjukkan adanya perbedaan semangat pada pemuda di Indonesia. 54,1\% mengungkapkan bahwa mereka lebih bersemangat dan bekerja keras dari dalam dirinya sendiri. Maksudnya adalah mereka lebih cepat bangkit dan bisa berkespresi jauh lebih baik ketika pemuda tersebut memiliki semangat juang tinggi yang berasal dari dirinya. Memang hal ini sangat jarang terjadi, tetapi tidak ada yang tidak mungkin selama ada usaha dan niat tentulah suatu semangat untuk menggapai cita dan mengharumkan bangsa dan negara akan semakin terlihat. Berbeda dengan 45,9\% pemuda mengatakan bahwa semangat dari orang lain adalah hal yang perlu dan sangat dibutuhkan bagi mereka. Mereka beranggapan bahwa yang bisa mengerti dirinya adalah ketika dia bertanya kepada orang lain atau bertanya kepada orang yang menurutnya tepat. Dengan begitu, semangat mereka untuk bisa mengharumkan bangsa dan negara menjadi semakin bertambah.

Segala hal yang berakitan dengan kebaikan mmang dalam peingmplementasiannya tidak semudah membalik kedua telapak tangan. Begitu juga dengan tokoh Kumbakarna dalam Serat Ramawijaya. Dia harus berjuang mati-matian demi negara Ngalengka tidak terpecah belah atau mungkin rusak hanya karena perilaku Rahwana menculik Sita dari genggaman Sang Prabu Ramawijaya. Dengan mempelajari poin yang berupa kerja keras ini kita diharapkan mampu membangun semangat dari diri kita sendiri. Pepatah mengatakan bahwa "Temen bakal tinemu" ketika kita bersungguh-sungguh dalam hal apapun kita juga akan mendapat sesuai dengan apa yang kita harapkan. Sebab sekeras apapun proses tidak akan pernah menghianati hasil yang maksimal.

\section{SIMPULAN}

Atas dasar hasil dan pembahasan pada penelitian mengenai relevansi tokoh Kumbakarna dalam Serat Ramawijaya sebagai refleksi semangat patriotisme pemuda Indonesia ini dapat disimpulkan mengenai dua pembahasan utama. Pembahasan yang pertama adalah mengenai deskripsi tokoh Kumbakarna, dalam deskripsi tersebut dinyatakan bahwa Kumbakarna merupakan sosok yang penuh dengan keberanian. Tidak hanya keberanian yang utama akan tetapi juga disebutkan bahwa Kumbakarna adalah sosok yang penuh strategi. Ia mengetahui kapan ia maju dan mengetahui lawannya untuk segera bergegas dalam medan perang. Poin ketiga yakni disebutkan bahwa Kumbakarna memiliki sikap nasionalisme yang sangat tinggi, terbukti pada kecintannya terhadap negara Ngalengka. Kekuatan dari Kumbakarna juga menjadi hal yang sangat patut untuk dicontoh. Keikhlasannya sebagai raksasa yang memiliki kebiasaan tidur yang tidak lumrah tidak melunturkan semangat patriotismenya terhadap negara Ngalengka. Hingga akhirnya Kumbakarna gugur di medan perang demi menyelamatkan negara Ngalengka dari suatu yang terpecah belah. 
Deskripsi yang kedua adalah mengenai relevansi tokoh Kumbakarna dalam Serat Ramawijaya sebagai refleksi semangat patriotisme pemuda di Indonesia. Hal pertama pada relevansinya ini adalah mengenai refleksi kepada pemuda agar bisa membangkitkan sikap kesatuan dan persatuan berupa semangat bela negara. Selain itu agar pemuda juga bisa mengedepankan perilaku sabar untuk mencapai tujuan suatu bangsa. Hal ini dikarenakan kesabaran adalah kunci keberhasilan dari jayanya suatu negara. Poin ketiga adalah memberi keteladanan bagi pemuda di Indonesia agar tidak membeda-bedakan antara suku, ras, budaya. Hal ini dikarenakan suatu persatuan harus dilandasi atas sikap penghormatan sesame warga negara apalagi dalam mebcapai bela negara yang tinggi harus benar-benar dan perlu diperhatikan. Untuk yang terakhir adalah mengenai sikap gigih dan tidak mudah putus asa. Melalui paparan tersebut kita bisa mengetahui bagaimana peran pemuda Indonesia di zaman yang penuh tantangan ini. Tanpa kita sadari pemuda adalah impian di masa mendatang yang memikul segala beban yang harus diselesaikan. Siapapun pemuda di Indoneisa harus berani mengambil konsekuensi jika dia ingin berhasil dalam mencapai suatu kesuksesan.

\section{DAFTAR PUSTAKA}

Ariani. (2020). Etika dalam Lakon Kumbakarna Gugur. Yogyakarta: Fakultas Filsafat UGM Yogyakarta

Bakry, Noor. (2010). Pendidikan Kewarganegaraan. Yogyakarta: Pustaka Belajar

Dover, R \& Phytian, M. (2011). Lost over Libya:the 2010 strategic defence and security reviewan obituary. Journal Defence Studies. 11(3), 420-444. Diunduh dari: https://doi.org./10.1080/

Elfindri. (2012). Pendidikan Karakter: Kerangka, Metode,dan Aplikasi untuk Pendidikan dan Profesional. Jakarta: Baduose Media.

Fathurahman, Oman. (2015). Filologi Indonesia: Teori dan Metode. Jakarta: Prenada Media. Gunawan, Heri. (2012). Pendidikan Karakter Konsep dan Implementasi.Bandung: Alfabeta

Gunawan, Imam. (2013). Metode Penelitian Kualitatif. Teori dan Praktik. Jakarta: PT Bumi Aksara

I Wayan, dkk.(2020). Kajian Nilai Pendidikan Karakter Tokoh Kumbakarna dalam Meningkatkan Mutu Nasionalisme. Jurnal Penjaminan Mutu. 6 (2). 1-9. Diunduh dari: http://ejournal.ihdn.ac.id/index.php/JPM

Mustari, Mohamad. (2011). Nilai karakter : Refleksi untuk Pendidikan Karakter. Yogyakarta: Laksbang Pressindo

Purnomo, Bambang. (2013). Filologi dan Studi Satra Lama. Surabaya: Penerbit Bintang Surabaya Putri, dkk. (2015). Hubungan Tingkat Pemahaman Konsep Pertahanan dan Keamanan Bangsa Indonesia dengan Sikap Patriotisme. Jurnal Kultur Demokrasi, 3(1). 1-13. Diunduh dari: http://journal2.um.ac.id/index.php/jkd

Slameto. (2010). Belajar dan Faktor-faktor yang Mempengaruhinya. Jakarta: PT.Rineka Cipta Sugiyono. (2017). Metode Penelitian Kualitatif, Kuantitatif, dan R\&d. Bandung: Alfabeta

Wijayanto, Rahmat.(2018). Pendidikan Bela Negara sebagai Tonggak Peradaban Jiwa Patriotisme Generasi Muda. Jurnal Ilmiah Pendidikan Pancasila dan Kewarganegaraan. 3(2). 1-6. Diunduh dari: http://journal2.um.ac.id/index.php/jipk

Winarno. (2013). Paradigma Baru Pendidikan Kewarganegaraan. Jakarta: PT.Bumi Aksara Yasa, I Nyoman. (2012). Teori Sastra dan Penerapannya. Bandung: Karya Putra Darwati. 